\title{
TERMINALIA CHEBULA: SUCCESS FROM BOTANY TO ALLOPATHIC AND AYURVEDIC PHARMACY
}

\author{
VARUN GARG, BARINDER KAUR, SACHIN KUMAR SINGH*, BIMLESH KUMAR
}

\author{
Department of Pharmacy, School of Pharmaceutical Sciences, Lovely Professional University, Phagwara, Punjab, India. \\ Email: singhsachin23@gmail.com/sachin_pharma06@yahoo.co.in
}

Received: 25 May 2016, Revised and Accepted: 27 May 2016

\section{ABSTRACT}

Terminalia chebula (TC) is a unique herb having various therapeutic potentials as anti-inflammatory, antioxidant, anticancer, and digestant. It belongs to family Combretaceae. In the present review, an attempt has been made to decipher classification, chemical constituents, therapeutic uses, and patents that have been reported for TC. Various pharmacological activities of TC that make it as potential medicine and its Ayurvedic formulations are highlighted.

Keywords: Terminalia chebula, Anti-oxidant, Anti-cancer, Ayurvedic formulations, Anti-oxidant.

(C) 2016 The Authors. Published by Innovare Academic Sciences Pvt Ltd. This is an open access article under the CC BY license (http://creativecommons. org/licenses/by/4. 0/) DOI: http://dx.doi.org/10.22159/ajpcr.2016.v9i5.13074

\section{INTRODUCTION}

Terminalia chebula (TC) is a unique herb that is used from ancient time since Charak. It is used in many herbal formulations like Triphala. It is used as anti-inflammatory and digestant [1-3]. In recent years, an extract of TC has been reported for having anticancer and antioxidant properties [1-3]. TC belongs to Kingdom: Plantae, Division: Magnoliophyta, Class: Magnoliopsida, Order: Myrtales, Family: Combretaceae, Genus: Terminalia, Species: Chebula Rtz [4,5].

It is known by different names in different languages such as Harad in Hindi, Haritaki in Sanskrit, Chebulic myrobalan in English, Karakkaya in Telugu, and in Tamil known as Kadukkai. Some other synonyms of TC are Amrta, Abhaya, Kayastha, Vayastha, Pathya, Vijaya, Siva Jaya, and Haimavti.

\section{CATEGORIZATION OF TC AS PER AYURVEDA}

TC has different varieties and the information of these varieties differ in Ayurvedic and modern text [6,7].

\section{Categorization as per Bhavamisra}

Acharya Bahvmishra mentioned about different varieties of Haritaki in his text. He explained about number of different varieties along with their uses are given below:

1. Vijya - used for sarvarog (all diseases)

2. Rohini - used as varan (bearing wound healing property)

3. Putana - used as pralepa (external applications)

4. Amrta-used for shodhan (purification procedures)

5. Abhya - used for netrarog (eye diseases)

6. Jivani-used for sarvarog (all diseases) [6].

\section{Categorization as per Indian Materia Medica}

Different varieties along their morphological characters and uses according to Indian Materia Medica are given below.

\section{Survariharade}

Large, dense and heavy size about 2 " long, yellowish to brownish in color, when cut it contains pulp of yellowish to brownish tinge. This variety is valuable purgative.

\section{Rangariharade}

These are smaller in size, less wrinkled, and less furrowed than Survariharade and its length is about one inch; when cut it presents a yellow dried pulp and stone. The pulp is also less astringent than above variety. These are alterative, stomachic, laxative, and tonic. It is generally used in fevers, cough, asthma, urinary diseases, piles, worms and rheumatism and scorpion-sting.

\section{Balaharade}

This variety is smaller than above two mentioned categories, its color is homogenous, and the pulp is deep brown. There is no stone into it. This is mild and safe aperients and antibilious, though astringent. Ripe fruits are considered as purgative removing bile and phlegm and to adjust bile. It is used in is highly useful in chronic diarrhea and dysentery, flatulence, vomiting, hiccups, colic and enlarged spleen and liver. Brayed with sugar and water it is used in ophthalmia.

\section{Java harade}

These are smallest than all of above varieties and rest characters are similar as that of Balaharade. The uses of this variety are similar as that of Balaharade. Along with that cold infusion of it is used as a gargle in sore mouth and stomatitis, spongy and ulcerated gums. Brayed in rose water it is a cooling application to swellings [8].

Categorization as per Hooker's flora of British India

In Hooker's flora of British India, apart from TC, six other varieties of TC are mentioned $[9,10]$ :

\section{TC Retz. (variety chebula proper)}

Fruits, one-to one-and-a-half inches, ellipsoidal or obovoid, from a broad base, more or less glabrous, and five-ribbed are abundant in Northern India at 1000-3000 ft.

\section{TC (var. typica)}

They have a young ovary and are shaggy without calyx teeth. They are distributed in Deccan, Ceylon, and Burma.

\section{TC (var. citrina)}

They have a young ovary, are quite glabrous, with ovate fruit, and a round base. It is common in Northern India, from Kumaon to Bengal and in Chhota Nagpur.

\section{TC (var.)}

The fruits of this variety are much smaller than the other varieties. Generally found in Bihar up to an altitude of $1000 \mathrm{ft}$. 
TC (var. tomentella, Kurz)

Young ovary, are glabrous, fruit is ovoid, and hardly one inch in diameter.

\section{TC (var. gangetica Roxb.)}

They have fruits with brown silky hair, which covers the twigs. It may be a very good variety. The fruit is similar to that of chebula, distributed in Northwest India.

\section{TC (var. parviflora Thwaitos Enum.)}

They have fruits that are more acutely ribbed $[9,10]$.

Table 1 describes varieties of TC according to different ancient texts such as Raja Balabh Nighantu, Atreya Shamita, Harita Shmita, Saligram Nighantu, Raj Nighantu, Bhav Praksh Nighantu [11-13].

\section{CHEMICAL CONSTITUENTS}

TC mainly contains hydrolysable tannins as active constituent Chebulinic acid (CA) is the main active constituent present in TC. Other constituents are chubulagic acid and D-galloyl glucose, free tannic acid, gallic acid, ellagic acid, and resin myrobalanin. Anthraquinone glycosides, sennosidesare also found in TC $[1,3]$. These tannins contain phenolic carboxylic acid like gallic acid, ellagic acid, chebulic acid, and gallotannins such as 1,6 di- $O$-galloyl- $\beta$-D-glucose, 3,4,6 tri- $O$-galloyl$\beta$-D-glucose, 2,3,4,6 tetra- $O$-galloyl- $\beta$-D-glucose, and 1,2,3,4,6 pentaOgalloyl- $\beta$-D-glucose. Ellagitannin such as punacalagin, casurarinin corilagin, and terchebulin and others such as chebulanin, neochebulinic acid, chebulagic acid, and CA are also present in TC [1,3].

\section{ISOLATION AND EXTRACTION OF ACTIVE CONSTITUENTS PRESENT IN TC}

CA and chebulagic acid was extracted from TC by high-speed counter current chromatography method [3]. The solvent system used for this was n-hexane-ethyl acetate-methanol-water $(1: 20: 1: 20 \mathrm{v} / \mathrm{v})$. The partition coefficient at this solvent system for chebulagic acid was 0.65 and CA was 1.20 respectively. Using this process, Quanbin et al., in 2006 , extracted $33.2 \mathrm{mg}$ chebulagic acid and $15.8 \mathrm{mg}$ CA with a purity of 95.3 and $96.1 \%$ recovery from $300 \mathrm{mg}$ of TC crude extract [3]

Mahajan et al., in 2010, isolated CA from TC by reverse phase high performance liquid chromatography (HPLC). They isolate 8 compounds gallic acid, methyl gallate, ethyl gallate, chebulagic acid, tetra- $O$-galloyl$\beta$-D-glucose, ellagic acid, CA, and penta-Ogalloyl- $\beta$-D-glucose from TC. The purities were checked by spectroscopic methods. UV absorption maxima of the hydrolysable tannins obtained from TC is shown in Table 2 [4]

Pfundstein et al., in 2010, determined polyphenolic and other active constituents of TC and Terminalia harridan. It was reported that TC contained $61.8 \mathrm{~g} / \mathrm{kg}$ of chebulic ellagitannins. Out of this chebulagic acid was $24.2 \mathrm{~g} / \mathrm{kg}$. Methyl neochebulinate, chebulic acid, chebulanin and methyl neochebulagate were present in decreasing order, in the range 7.1-9.0 g/kg. The recovery of CA was $4 \mathrm{~g} / \mathrm{kg}$ along with small amounts of the partial hydrolyzed product $(0.11 \mathrm{~g} / \mathrm{kg})$. Methyl neochebulanin is $2.2 \mathrm{~g} / \mathrm{kg} .32 .2 \mathrm{~g} / \mathrm{kg}$ gallic acid and gallate ester were present. The non-chebulic ellagitannins $(25.0 \mathrm{~g} / \mathrm{kg})$ were represented by about equal amounts of corilagin and punicalagin. Ellagic acid was present at $4.1 \mathrm{~g} / \mathrm{kg}$ [5]. In TC and its related plants, tannins are the main biologically active substances. They are present in different molecular forms such as dimers, tetramers and polymers, depending on the mode of extraction. In aqueous or ethanolic extracts the lower molecules are prevalent.

Klika et al., in 2004 extracted and isolate 1,3,6-Tri- $O$-galloyl-2,4chebuloyl- $\beta$-D-glucopyranoside (CA) and its novel thrice hydrolyzed derivative, 2,4-chebuloyl- $\beta$-D-glucopyranoside (galloyl-free CA), together with ellagic and gallic acids, ethyl gallate, and luteolin, from the dried fruit of TC. They also identified and confirmed structure by UV, MS, and NMR data [14].
Table 1: Evidences of different varieties of TC in ancient Ayurvedic literature [11-13]

\begin{tabular}{lllll}
\hline $\begin{array}{l}\text { Serial } \\
\text { number }\end{array}$ & $\begin{array}{l}\text { Varieties } \\
\text { of } \\
\text { Haritaki }\end{array}$ & $\begin{array}{l}\text { Harita Shmita, } \\
\text { Saligram Nighantu, } \\
\text { Raj Nighantu, Bhav } \\
\text { Praksh Nighantu }\end{array}$ & $\begin{array}{l}\text { Raja } \\
\text { Balabh } \\
\text { Nighantu }\end{array}$ & $\begin{array}{l}\text { Atreya } \\
\text { Shamita }\end{array}$ \\
\hline 1 & Abhaya & Yes & Yes & Yes \\
2 & Amrita & Yes & Yes & No \\
3 & Chetaki & No & No & Yes \\
4 & Haimvati & No & No & No \\
5 & Jaya & No & No & No \\
6 & Jivanti & Yes & Yes & Yes \\
7 & Kalika & No & Yes & No \\
8 & Pathya & No & No & No \\
9 & Putana & Yes & Yes & Yes \\
10 & Rohani & Yes & Yes & No \\
1 & Vijaya & Yes & Yes & No \\
\hline
\end{tabular}

TC: Terminalia chebula

Table 2: UV wavelength of hydrolysable tannins [4]

\begin{tabular}{|c|c|c|}
\hline $\begin{array}{l}\text { Hydrolysable } \\
\text { tannins }\end{array}$ & Physical property & $\begin{array}{l}\mathrm{UV} \lambda \text { max } \\
(\mathrm{nm})\end{array}$ \\
\hline Gallic acid & White amorphous powder & 215,271 \\
\hline Methyl gallate & White amorphous powder & 215,271 \\
\hline Ethyl gallate & White amorphous powder & 215,271 \\
\hline Chebulagic acid & Pale yellow powder & 222,276 \\
\hline $\begin{array}{l}\text { Tetra- } O \text {-galloyl- } \\
\beta \text {-D-glucose }\end{array}$ & Pale yellow powder & 217,278 \\
\hline Ellagic acid & White powder & 253,364 \\
\hline Chebulinic acid & Pale yellow powder & 222,276 \\
\hline $\begin{array}{l}\text { Penta- } O \text {-galloyl- } \\
\beta \text {-D-glucose) }\end{array}$ & Pale yellow powder & 217,278 \\
\hline
\end{tabular}

UV: Ultraviolet

Mahajan et al., in 2011 found significant variation in active constituent of three market samples of TC churna. They used HPLC method for quantification and qualification of the sample. Due to this variation, it is better to use active constituent [15]

Hydrolysable tannins on treatment with hydrochloric acid and sulfuric acid yield gallic or ellagic acid [16].

\section{RASA PANCHAK: PROPERTIES OF TC AS PER AYURVEDA}

Rasa (Taste) - Madhura, Amla, Tikta, Katu, Kahasaya

Guna (Property) - Laghu, Ruksha

Veerya (Dynamic property or Potency) - Ushna

Vipaka (Digestive stage) - Madhur

Prabhav (Distinctive action) - Tridosha shamak

The above mentioned different Rasas (taste) present in different parts of TC fruit.

Fruits of TC contain five Rasas (Taste),

1. Madhur - (sweet) - the fruit pulp

2. Amla - (sour) - the bulky portion of the fruit

3. Tikta - (bitter) - seeds

4. Katu - (Pungent) - the covering of the fruit

5. Kahasaya - (astringent) - the hard portion of the seed [7]

\section{PHARMACOLOGICAL AND THERAPEUTIC ACTIVITIES}

In ancient time, Charaka mentioned the use of TC in Javaraghna, Arsoghan, Kasaghan, Kusthaghna, Prajasthapana, while Susrutaused TC in Amalakyadi, Parusakdi, Triphala, and Vagbhatt used in Parusakadi. Gogotey has mentioned both internal and external uses. In external uses, it is mentioned that TC is used for inflammation, conjunctivitis and 
it can used on the eyelids. Decoction of Haritaki is used for the washing of wounds. In combination with Phyllanthus emblica and Terminalia bellirica under the name Triphala, fruits of TC are extensively used as adjunct to other medicines in almost in almost all diseases [17] Triphala had also been found to be anti-inflammatory activity in gouty arthritis [18].

\section{Anti-inflammatory activity}

Sabina et al., in 2008, in showed anti-inflammatory activity in monosodium urate crystal-induced inflammation in mice of Triphala. They showed its significance in gouty arthritis [18].

Reddy et al., in 2009, showed that chebulagic acid is the compound in $\mathrm{TC}$ responsible for anti-inflammatory activity. They showed that chebulagic acid inhibit COX and 5-LOX responsible for antiinflammatory and anticancer activity. Chebulagic acid showed potent COX-LOX dual inhibition activity with IC50 values of $15 \pm 0.288$, $0.92 \pm 0.011$ and $2.1 \pm 0.057 \mu \mathrm{M}$ for COX1, COX2, and 5-LOX, respectively They also showed apoptosis by chebulagic acid in COLO 205 cells. While ethanolic extract of TC showed IC 50 for COX1 and COX2 and LOX is $90 \mu \mathrm{g} / \mathrm{ml}, 3.75 \mu, 20 \mu \mathrm{g} / \mathrm{m}[19]$.

\section{Anti-viral activity}

Extract of TC has antiviral properties [20]. Ma et al., in 2010, demonstrated the antiviral activity of acetone extract of TC. They used mixture of Tannic acid and TC, instead of a single compound in order to get synergistic action of mixture. They showed the activity of acetone extract against swine influenza A virus [21].

\section{Anti-cancer activity}

It is used traditionally as anticancer drug in Africa and Asia. Saleem et al., in 2002, showed in vitro anticancer activity of methanolic extract of TC. Cytotoxicity of Terminalia phenolics in HOS-1 cells was determined by the level of adenosine triphosphate (ATP). IC50 of CA was reported to be $53.2 \mu \mathrm{M}$ [22]. Anticancer activity of $70 \%$ methanolic extract of TC was shown on cell lines of human (MCF-7), mouse (S115) breast cancer cell line, human osteosarcoma cell line, human prostate cancer cell line (PC-3), non-tumorigenic, and immortalized human prostate cell line (PNT1A). The parameters used to prove anticancer activity were proliferation thymidine incorporation and coulter counting. Cell viability was determined by ATP determination. The results revealed that concentration of $100 \mu \mathrm{g} / \mathrm{ml}$, inhibit cell growth. It took some time to start its effect due to initiation of cellular processes causing decrease in proliferation and cell death. But at concentration of $400 \mu \mathrm{g} / \mathrm{ml}$, it showed direct cytotoxic effect. The main components responsible for this action are CA, tannic acid, and ellagic acid [22].

CA is reported to inhibit HeLa cancer cell of cervical carcinoma. Although action of CA was restoration of gap junctional intracellular communication, exact mechanism is unknown [23].

Tannin extract of TC possess antimutagenic properties. Kaur et al., in 1998, showed that galic acid derivative and other tannins have antimutagenic activity against S9-dependent mutagen and $2 \mathrm{AF}$ in Salmonella typhi [24].

Prasad et al., in 2006, showed the chemomodulatory effect of TC in Wister rat against nickel induced oxidative stress. Nickel chloride treatment caused an increase in tumor promoters. The treatment of rat with TC with $25 \mathrm{mg} / \mathrm{kg}$ body weight dose reduces effect of nickel chloride. Thus, its extract can also be used in the prevention of cancer [25].

Chebulagic acid also has anticancer properties. TC is used to cure and stomach cancers [26]. It has 5-LOX inhibitory action $2.1 \pm 0.057 \mu \mathrm{M}$. It had demonstrated anticancer properties against HCT-15 (colon), COLO-205 (colon), MDA-MB-231 (breast), DU- 145 (prostate), and K562 (chronic myeloid leukemia) cancer cell lines. It also showed antiproliferative activity against HCT-15, COLO-205, MDA-MB-231, DU-145, and K562 cell lines [19].
Cardiac effect

CA has anti-hypertensive properties. This effect may be due to decrease in cardiac output which causes reduced left ventricular contraction. Hydrolysable tannins potentiate activity of beta-adrenergic blocker by depressing muscle contraction $[27,28]$. Mitochondria play an important role at molecular level in ischemia. Pretreatment of alcoholic extract of TC at dose of $50 \mathrm{mg} / 100 \mathrm{~g}$ body weight had protective action in isoproterenol (ISO) (at dose $20 \mathrm{mg} / 100 \mathrm{~g}$ body weight) induced toxicity in rats. It was reported that TC retains normal function of mitochondria in ISO induced toxicity [29].

\section{Antihyperlipidemic activity}

TC has hypocholestemic effect. Thakur et al., in 1988 showed hypocholestemic effect in rabbits. Authors reported that TC has more lipid lowering activity than Amla and Bahera and it could be used as antihyperlipidemic agent for the treatment of atherosclerosis [30].

\section{Antidiabetic activity}

Aqueous extract of TC has been reported to have antidiabitic activity. Chebulic acid has protective action in case of glycation induced end product that causes endothelial cell dysfunction. According to Lee et al., in 2011, chebulic acid had IC50 values of $17.1 \mathrm{mM}$ for protein cross-linking and $1.32 \mathrm{mM}$ for advanced glycation end products (AGE) formation. As a positive control, aminoguanidine had IC50 values of $21.3 \mathrm{mM}$ and $2.37 \mathrm{mM}$, respectively. They treat human umbilical vein endothelial cell with chebulic acid in the presence of AGEs. Due to chebulic acid dose-dependent reduction glycer-AGE induced formation to $108.2 \pm 1.9 \%$ for $25 \mu \mathrm{M}$ versus $137.8 \pm 1.1 \%$ for glycer-AGEs treated alone. They showed chebulic acid may be an agent can be used in diabetic vascular complication [31].

Aqueous methanolic extract of TC has been reported to have alphaglucosidase inhibitory action. This extract has been reported to inhibit the inhibitory action of maltase that is present in rat's intestine. Chebulanin, chebulagic acid, and CA have malatase inhibitory action with IC50 of 690,97 and $36 \mu \mathrm{M}$, respectively. CA also has potent alpha-glucosidase inhibitory action. Thus, chebula and CA can be used in treatment and control of diabetes specially in type 2 diabetes [32].

It is also reported that TC possesses dose-dependent anti-diabetic activity in lowering blood glucose of streptozotocin induced diabetic rats [33].

\section{Radioprotective action}

TC extract has been found to possess radioprotective action in mice. Damage to DNA due to radiation was reduced [33,34]. TC along with other herbs (Triphala) is shown to be radioprotective properties at a dose of $10 \mathrm{mg} / \mathrm{kg}$ when administered intraperitonealy in mice. It acts by scavenging free radicals that are produced by radiation [35].

\section{Anti-ulcer activity}

TC has antiulcer properties. Sharma et al., in 2011, showed antiulcer activity [26]. It acts by inhibiting action of Helicobacter pylori by inhibiting urease activity which is responsible for ulcers in stomach. It

Table 3: Vehicles used for TC according to season [6]

\begin{tabular}{lll}
\hline $\begin{array}{l}\text { Serial } \\
\text { number }\end{array}$ & Seasons (Ritu) & $\begin{array}{l}\text { Vehicle used for } \\
\text { administration } \\
\text { of TC (Anupaan) }\end{array}$ \\
\hline 1 & Illavenil (midly sunny) & Honey \\
2 & Muthuvenil (intense sunny) & Jaggery \\
3 & Kar (cloudy rainy) & Rock salt \\
4 & Kuthir (Cold) & Sugar \\
5 & Munpani (Early misty) & Dried ginger \\
6 & Pinpani (Late misty) & Long pepper \\
\hline TC: Terminalia chebula &
\end{tabular}


Table 4: Various patents on TC [43-88]

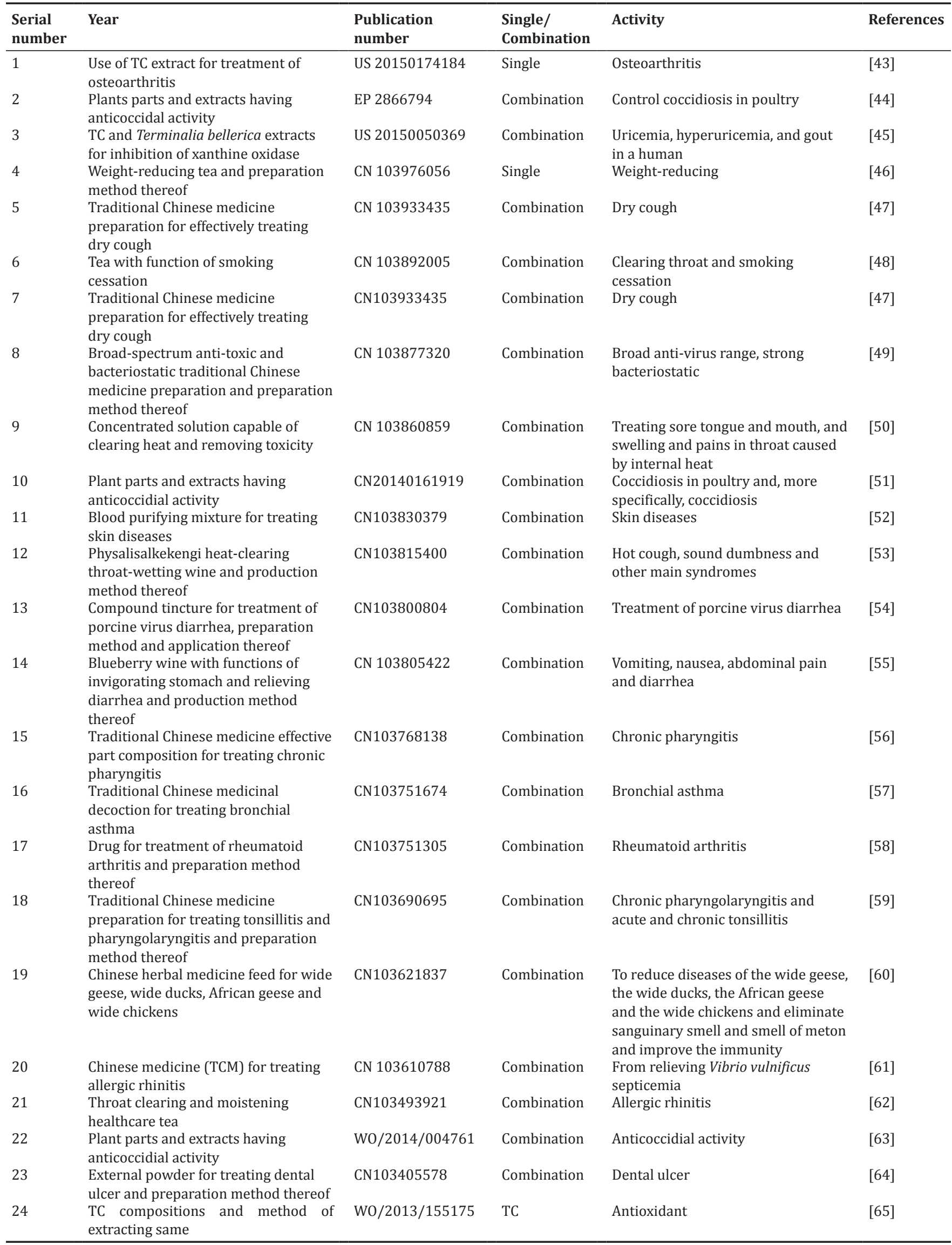


Table 4: (Continued)

\begin{tabular}{|c|c|c|c|c|c|}
\hline $\begin{array}{l}\text { Serial } \\
\text { number }\end{array}$ & Year & $\begin{array}{l}\text { Publication } \\
\text { number }\end{array}$ & $\begin{array}{l}\text { Single/ } \\
\text { Combination }\end{array}$ & Activity & References \\
\hline 25 & $\begin{array}{l}\text { Inhibitor and a breaker of an } \\
\text { AGE-products - induced crosslink, } \\
\text { containing chebulic acid as an active } \\
\text { ingredient }\end{array}$ & Kr 1020130109874 & $\mathrm{TC}$ & Antioxidant & {$[66]$} \\
\hline 26 & $\begin{array}{l}\text { Mouthwash composition for managing } \\
\text { oral mucositis, process and methods } \\
\text { thereof }\end{array}$ & US20130243702 & Combination & Oral mucositis & [67] \\
\hline 27 & $\begin{array}{l}\text { Quality control method of drug for } \\
\text { treating cough }\end{array}$ & CN103175938 & Combination & Treating cough & {$[68]$} \\
\hline 28 & $\begin{array}{l}\text { Cosmetic composition containing } \\
\text { Indian natural products for skin } \\
\text { whitening }\end{array}$ & Kr 1020130057542 & Combination & Skin whitening & [69] \\
\hline 29 & $\begin{array}{l}\text { A Chinese medicinal formulation } \\
\text { for treating infiltrative pulmonary } \\
\text { tuberculosis }\end{array}$ & CN102847026 & Combination & Pulmonary tuberculosis & {$[70]$} \\
\hline 31 & $\begin{array}{l}\text { Traditional Chinese medicine for } \\
\text { treating fungal skin infection }\end{array}$ & CN102824518 & Combination & Skin fungal infection & {$[72]$} \\
\hline 32 & $\begin{array}{l}\text { Traditional Tibetan medicine for } \\
\text { treating alopecia }\end{array}$ & CN102784216 & Combination & Alopecia & {$[73]$} \\
\hline 33 & $\begin{array}{l}\text { Traditional Chinese medicine } \\
\text { preparation for treating viral enteritis } \\
\text { and diarrhea }\end{array}$ & CN102670936 & Combination & Viral enteritis and diarrhea & {$[74]$} \\
\hline 34 & $\begin{array}{l}\text { Herb extract for cognitive health } \\
\text { benefit }\end{array}$ & EP2486932 & Combination & Cognitive health benefit & {$[75]$} \\
\hline 35 & $\begin{array}{l}\text { Antioxidant active compound of TC } \\
\text { and preparation method thereof }\end{array}$ & CN102526136 & Single & $\begin{array}{l}\text { Antioxidant activity, tyrosinase } \\
\text { inhibitory activity, bacteriostatic } \\
\text { action and cell protection effect }\end{array}$ & {$[76]$} \\
\hline 36 & Hair treatment composition & EP2467191 & Single & Permanent hair dye & [77] \\
\hline 37 & Hair treatment composition & US20120138079 & Single & Hair dye & [78] \\
\hline 38 & $\begin{array}{l}\text { A mouthwash composition for } \\
\text { managing oral mucositis, process and } \\
\text { methods thereof }\end{array}$ & WO/2012/059874 & Combination & Oral mucositis in cancer patients & [79] \\
\hline 39 & $\begin{array}{l}\text { Plant extracts, compositions } \\
\text { containing same, and uses thereof }\end{array}$ & US20120027697 & Combination & Cosmetics & {$[80]$} \\
\hline 40 & $\begin{array}{l}\text { Chinese composition for treating } \\
\text { rhinitis }\end{array}$ & CN102284035 & Combination & Rhinitis & [81] \\
\hline 41 & $\begin{array}{l}\text { Pharmaceutical composition } \\
\text { containing TC retzius extract for or } \\
\text { treating dermatitis }\end{array}$ & Kr1020110108825 & Single & Dermatitis & [82] \\
\hline 42 & $\begin{array}{l}\text { Screening method (metabolite grid) } \\
\text { for therapeutic extracts and molecules } \\
\text { for diabetes }\end{array}$ & US20110159118 & Combination & Diabetes & [83] \\
\hline 43 & $\begin{array}{l}\text { NF-kappa B inhibitor containing TC } \\
\text { fruit extract }\end{array}$ & Kr1020110073241 & Single & $\begin{array}{l}\text { NF-kappa B activation increase- } \\
\text { associated diseases }\end{array}$ & [84] \\
\hline 44 & $\begin{array}{l}\text { Compound TC Retz. throat lozenge } \\
\text { and preparation method thereof }\end{array}$ & CN102100326 & Single & $\begin{array}{l}\text { Reducing fever, relieving the sore } \\
\text { throat and promoting the production } \\
\text { of the body fluid and has the } \\
\text { advantages of excellent mouth feel }\end{array}$ & [85] \\
\hline 45 & $\begin{array}{l}\text { Method for preparing TC extract for } \\
\text { preventing or treating prostate cancer }\end{array}$ & Kr1020110048133 & Single & Prostate cancer & {$[86]$} \\
\hline 46 & Hair treatment composition & WO/2011/020833 & Single & Permanent hair dye & [87] \\
\hline
\end{tabular}

is reported that aqueous extract has strong anti $H$. pylori activity.It also improvers the activity of bruneres gland, thus helpful in the treatment of duodenal ulcers [33].

\section{Anti HIV activity}

CA present in TC has anti HIV properties. CA act by inhibiting binding of HIV rgp20 to CD4. CA was found to non-toxic at dose up to 10 times [36]. Several hydrolysable tannins inhibit the expression of HIV antigen present in human lymphotropic virus type 1-postive MT-4 cells. These tannins inhibit HIV adsorption on cells [37].

\section{Antioxident activity}

Aqueous extract of TC has antioxidant properties. Extract of TC is found to have more antioxidant properties than Momordica charantia, Glycyrrhiza glabra, and Acacia catechu. Aqueous extract of TC had antioxident activity by IC 50 by thiobarbituric acid reactive substances is $14.5 \mu \mathrm{g} / \mathrm{ml}$, IC50 by $\mathrm{DPPH}$ is $11.5 \mu \mathrm{g} / \mathrm{ml}$, and ascorbate equivalent is 60\% [38].

Chebulagic acid has antioxidant properties. It has DPPH radical scavenging activity with IC50 of $1.4 \mu \mathrm{M}$ and strong inhibition of ABTS radical with an IC50 value of $1.7 \pm 0.023 \mu \mathrm{M}$ [19] 
TC had antioxidant properties due to the presence of hydrolysable tannins [39]. Tannins were found to have more potent antioxidant activity than flavonoids [40]. Chebulinic and chebulagic acid, both were found to have antioxidant properties $[14,19,41]$. CA has been reported for better antioxidant activity than other tannins due to higher DPPH activity [5].

\section{Hepatoprotective action}

TC extract has hepatoprotective action against rifampicin, isoniazid, and pyrazinamide toxicity [33]. Hydrolyzable tannins generally exhibit an intense enzyme inhibitory action on glutamic-pyruvic transaminase [42]

\section{Miscellaneous}

Adrenocorticotropic hormone-induced lipolysis could be enhanced by CA and tellimagrandin I at 5-100 g/ml [41]. TC and its extract are used in wound healing and as antispasmodic. It has antibacterial properties also. It is used as anticaries agentin mouth washes. It has been used to treat respiratory disorders in Ayurveda. It is also reported to be used in urticarea and skin allergies. It has also been found to have purgative and antiamoebic action [26,33].

\section{FORMULATIONS AND PREPARATIONS}

TC is a rejuvenating medicinal fruit and it is used with different vehicles for the rejuvenation of body. Different formulations and ayurvedic preparations of TC available are Abhayamodaka, Abhayarishta, Pathyadivati, Pathyadikwath, Vyaghriharitaki, Haritikileha, Chitrakharitaki, Agastiharitaki, Dantiharitki, Haritakikhanda Pathyadichurna, Abhayadiguggulu, Abhayadikalka, Amritaharitaki, Abhyaamalakiyarasayana, and Kayakalpa. To act as Kayakalpa, it should be consumed with different vehicles according to the season as shown (Table 3) [6]. Various patents related to TC are depicted in Table 4.

From the medicinal point of view, most of tannins of TC bring good results. They are effective against bacteria, viruses, parasites, and cancer cells. They protect animals and organs with their antioxidant property. They are reported to be nearly not toxic. But because there are no dosages known for the use in humans, they cannot be recommended for the internal use in humans [26]. YI et al., in 2004, showed that IC50 of CA for erythroid differentiation was $40 \mu \mathrm{mol} / \mathrm{L}$ for hemin-induced cell and $4 \mu \mathrm{mol} / \mathrm{L}$ for BA induced cells, respectively. CA has an inhibitory effect on erythroid differentiation of K-56 cells [88]

\section{CONCLUSION}

TC is a unique herb having various therapeutic potential as antiinflammatory, antioxidant, anticancer, and digestant. Classification, chemical constituents, therapeutic uses, and patents that have been reported for TC. Various pharmacological activities of TC that make it as potential medicine and its Ayurvedic formulations are highlighted.

\section{REFERENCES}

1. Bag A, Kumar Bhattacharyya S, Kumar Pal N, Ranjan Chattopadhyay R. Anti-inflammatory, anti- lipid peroxidative, antioxidant and membrane stabilizing activity of hydroalcoholic extract of Terminalia chebula fruits.Pharm Biol 2013;5(12):1515-20.

2. Jami SI, Sultana Z, Ali E, Begum M, Haque M. Evaluation of analgesic and anti - Inflammatory activities on ethanolic extract of Terminalia chebula fruits in experimental animal models. AJIPS 2014;5(1):63-9.

3. Han Q, Song J, Qiao C, Wong L, Xu H. Preparative isolation of hydrolysable tannins chebulagic acid and chebulinic acid from Terminalia chebula by high-speed counter-current chromatography. J Sep Sci 2006;29(11):1653-7.

4. Mahajan A, Pai N. Simultaneous isolation and identification of phytoconstituents from Terminalia chebula by preparative chromatography. J Chem Pharm Res 2010;2(5):97-103.

5. Pfundstein B, El Desouky SK, Hull WE, Haubner R, Erben G, Owen RW. Polyphenolic compounds in the fruits of Egyptian medicinal plants (Terminalia bellerica, Terminalia chebula and Terminalia horrida): Characterization, quantitation and determination of antioxidant capacities. Phytochemistry 2010;71(10):1132-485.
6. Sastry JL. Dravyaguna Vijnana. Vol. 2. Reprint 2008. Varanasi: Chaukhambha Orientalia; 2008. p. 210.

7. Gogte UV. Ayurvedic Pharmacology and Therapeutic uses of Medicinal Plants. Reprint 2009. New Delhi: Chaukhamba Orientalia; 2009. p. 515-9.

8. Nadkarni AK. Indian Materia Medica. Reprint 2010. Mumbai: Popular Prakashan; 2010. p. 2016.

9. Hooker JD. Flora of British India. Part-2. London: Oxford; 1854. p. 443-9.

10. Ratha KK, Joshi GC. Haritaki (Chebulic myrobalan) and its varieties. Ayu 2013;34(3):331-4.

11. Chunekar KC. Bhavaprakash Nighantu. Varanasi: Chaukhamba Bharati Academy; 1999. p. 4-5.

12. Sharma PV, Sharma GP. Nighantu of Kaiyadeva. $1^{\text {st }}$ ed. Varanasi: Chaukhamba Orientalia, Kaiyadevnighantu; 1979. p. 45.

13. Vaidya B. Nighantu Adarsa. $1^{\text {st }}$ ed. Varanasi: Chaukhambha Vidya Bhavan; 1968. p. 551-4

14. Klika KD, Saleem A, Sinkkonen J, Kähkönen M, Loponen J, Tähtinen $\mathrm{P}$, et al. The structural and conformational analyses and antioxidant activities of chebulinic acid and its thrice-hydrolyzed derivative, 2,4-chebuloyl- $\beta$-D-glucopyranoside, isolated from the fruit of Terminalia chebula. ARKIVOC 2004;7:83-105.

15. Mahajan AD, Pai NR. Development and validation of HPLC method for quantification of phytoconstituents in Haritaki churna. Int J Chem Tech Res 2011;3(1):329-36.

16. Tannins. Available from: http://www.pharmaxchange.info/ press/?s=tannins. [Last cited on 2014 Aug 12].

17. Sahrma PC, Yelne MB, Dennis TJ, Joshi A. Database on Medicinal Plants in Ayurveda. Vol. 2. Reprint 2005. New Delhi: Documentation and Publication Division, CCRAS; 2005. p. 29.

18. Sabina EP, Rasool M. An in vivo and in vitro potential of Indian Ayurvedic herbal formulation Triphala on experimental gouty arthritis in mice. Vascul Pharmacol 2008;48(1):14-20.

19. Reddy DB, Reddy TC, Jyotsna G, Sharan S, Priya N, Lakshmipathi V, et al. Chebulagic acid, a COX-LOX dual inhibitor isolated from the fruits of Terminalia chebula Retz. Induces apoptosis in COLO-205 cell line. J Ethnopharmacol 2009;124(3):506-12.

20. Oyuntsetseg N, Khasnatinov MA, Molor-Erdene P, Oyunbileg J, Liapunov AV, Danchinova GA, et al. Evaluation of direct antiviral activity of the Deva-5 herb formulation and extracts of five Asian plants against influenza A virus H3N8. BMC Complement Altern Med 2014; $14: 235$

21. Ma H, Diao Y, Zhao D, Li K, Kang T. A new alternative to treat swine influenza A virus infection: Extracts from Terminalia chebula Retz. Afr J Microbiol Res 2010;4(6):497-9.

22. Saleem A, Husheem M, Härkönen P, Pihlaja K. Inhibition of cancer cell growth by crude extract and the phenolics of Terminalia chebula Retz. Fruit. J Ethnopharmacol 2002;81(3):327-36.

23. Yi ZC, Liu YZ, Li HX, Yin Y, Zhuang FY, Fan YB, et al. Tellimagrandin I enhances gap junctional communication and attenuates the tumor phenotype of human cervical carcinoma Hela cells in vitro. Cancer Lett 2006;242(1):77-87.

24. Kaur S, Grover IS, Singh M, Kaur S. Antimutagenicity of hydrolyzable tannins from Terminalia chebula in Salmonella typhimurium. Mutat Res 1998;419(1-3):169-79.

25. Prasad L, Husain Khan T, Jahangir T, Sultana S. Chemomodulatory effects of Terminalia chebula against nickel chloride induced oxidative stress and tumor promotion response in male Wistar rats. J Trace Elem Med Biol 2006;20(4):233-9.

26. Sharma P, Prakash T, Kotresha D, Ansari MA, Sahrm UR, Kumar B, et al. Antiulcerogenic activity of Terminalia chebula fruit in experimentally induced ulcer in rats. Pharm Biol 2011;49(3):262-8.

27. Lee H, Lee JY, Suh MH, Sim SS, Lee MW, Kim CJ. Hydrolysable tannins depress cardiac papillary muscle contraction and propranololinduced negative inotropism. Fitoterapia 2010;81(7):820-5.

28. Guan YY, Kwan CY, Hsu FL, Cheng JT. In vitro inhibitory effects of chebulinic acid on the contractile responses of cardiovascular muscles. Clin Exp Pharmacol Physiol 1996;23(8):747-50.

29. Suchalatha $S$, Srinivasan $P$, Devi CS. Effect of $T$. chebula on mitochondrial alterations in experimental myocardial injury. Chem Biol Interact 2007;169(3):145-53.

30. Thakur CP, Thakur B, Singh S, Sinha PK, Sinha SK. The Ayurvedic medicines Haritaki, Amala and Bahira reduce cholesterol-induced atherosclerosis in rabbits. Int J Cardiol 1988;21(2):167-75.

31. Lee HS, Koo YC, Suh HJ, Kim KY, Lee KW. Preventive effects of chebulic acid isolated from Terminalia chebula on advanced glycation endproduct-induced endothelial cell dysfunction. J Ethnopharmacol 2010;131:567-74 
32. Sasidharan I, Sundaresan A, Nisha VM, Kirishna MS, Raghu KG, Jayamurthy P. Inhibitory effect of Terminalia chebula Retz. Fruit extracts on digestive enzyme related to diabetes and oxidative stress. J Enzyme Inhib Med Chem 2012;27(4):578-86.

33. Gupta A, Mishra AK, Bansal P, Singh R, Kumar S, Gupta V. Phytochemistry and pharmacological activities of Haritaki - A review. J Pharm Res 2010;3(2):417.

34. Gandhi NM, Nair CK. Radiation protection by Terminalia chebula: Some mechanistic aspects. Mol Cell Biochem 2005;277(1-2):43-8

35. Jagetia GC, Baliga MS, Malagi KJ, Sethukumar Kamath M. The evaluation of the radioprotective effect of Triphala (An Ayurvedic rejuvenating drug) in the mice exposed to gamma-radiation. Phytomedicine 2002;9(2):99-108.

36. Weaver JL, Pine PS, Dutschman G, Cheng YC, Lee KH, Aszalos A Prevention of binding of rgp120 by anti-HIV active tannins. Biochem Pharmacol 1992;43(11):2479-80.

37. Nakashima H, Murakami T, Yamamoto N, Sakagami H, Tanuma S, Hatano $\mathrm{T}$, et al. Inhibition of human immunodeficiency viral replication by tannins and related compounds. Antiviral Res 1992;18(1):91-103.

38. Naik GH, Priyadarsini KI, Satav JG, Banavalikar MM, Sohoni DP, Biyani MK, et al. Comparative antioxidant activity of individual herbal components used in Ayurvedic medicine. Phytochemistry 2003;63(1):97-104

39. Surveswaran S, Cai YZ, Corke H, Sun M. Systematic evaluation of natural phenolic antioxidants from 133 Indian medicinal plants. Food Chem 2007; 102:938-53.

40. Yokozawa T, Chen CP, Dong E, Tanaka T, Nonaka GI, Nishioka I Study on the inhibitory effect of tannins and flavonoids agains the 1,1-diphenyl-2 picrylhydrazyl radical. Biochem Pharmacol 1998;56(2):213-22

41. Okuda T. Systematics and health effects of chemically distinct tannins in medicinal plants. Phytochemistry 2005;66(17):2012-31.

42. Hikino H, Kiso Y, Hatano T, Yoshida T, Okuda T. Antihepatotoxic actions of tannins. J Ethnopharmacol 1985;14(1):19-29.

43. Kalidindi SR. Use of Terminalia chebula extract for treatment of osteoarthritis. US Patent 20150174184. 2014. Available from: https:/www.patentscope.wipo.int/search/en/result.jsf? currentNavigation Row $=$ next $\&$ prev CurrentNavigation Row $=1 \&$ query $=$ Terminalia $\%$ 20chebula\&office $=$ \&sortOption $=$ Pub $\% 20$ Date\%20Desc\&prevFilter $=\& \operatorname{maxRec}=579$. [Last cited on 2015 Oct 12].

44. Gokila T, Rajalekshmi M, Haridasan C, Eleke S, Hilde W, Ilse M Plants parts and extracts having anticoccidal activity. EP Paten 2866794. 2015. Available from: https://www.patentscope.wipo.int/ search/en/detail.jsf? docId= EP133271519\&recNum $=21 \&$ office $=$ \&queryString $=$ Terminalia + chebula\&prevFilter $=$ \&sortOption $=$ Pub+Date+Desc\&maxRec $=579$. [Last cited on 2015 Oct 12].

45. Kalidindi SR. Terminalia chebula and Terminalia bellerica extracts for inhibition of xanthine oxidase.US Patent 20150050369. 2015. Available from: https://www.patentscope.wipo.int/search/en/detail.jsf?docId= US130579967\&redirectedID $=$ true. [Last cited on 2015 Oct 12].

46. Rihua H. Weight-reducing tea and preparation method thereof. CN Patent 103976056. 2014. Available from: https://www.patentscope wipo.int $/$ search/en/detail.jsf?docId $=\quad \mathrm{CN} 107124602 \&$ redirectedID $=$ true. [Last cited on 2015 Oct 12].

47. Wuxian Z, Qunxing L, Yingting Z. Traditional Chinese medicine preparation for effectively treating dry cough. CN Patent 103933435 2014. Available from: https://www.patentscope.wipo.int/search/en/ detail.jsf?docId $=\mathrm{CN} 106893674 \&$ redirectedID $=$ true. [Last cited on 2015 Oct 12].

48. Jianhua C, Xiaoqun L, Yifeng L, Xiaoxia W. Tea with function of smoking cessation. CN Patent 103892005. 2014. Available from: https://www.patentscope.wipo.int/search/en/detail.jsf?docId= $\mathrm{CN} 105753730 \&$ redirectedID $=$ true. [Last cited on 2015 Oct 12]

49. Yongda Z, Fengying M, Haining F. Broad-spectrum anti-toxic and bacteriostatic traditional Chinese medicine preparation and preparation method there of. CN Patent 103877320. 2014. Available from: https://www.patentscope.wipo.int/search/en/detail.jsf?docId= $\mathrm{CN} 105724061 \&$ redirectedID $=$ true. [Last cited on 2015 Oct 12].

50. Hongxia Y. Concentrated solution capable of clearing heat and removing toxicity. CN Patent 103860859. 2014. Available from: https://www.patentscope.wipo.int/search/en/detail.jsf?docId= $\mathrm{CN} 105527443 \&$ redirectedID $=$ true. [Last cited on 2015 Oct 12]

51. Gokila T, Rajalekshmi M, Haridasan C, Hannah K. Plant parts and extracts having anticoccidial activity. US Patent 20140161919 2014. Available from: https://www.patentscope.wipo.int/search/en/ detail.jsf?docId $=$ US97881695\&redirectedID $=$ true. [Last cited on 2015 Oct 12]
52. Kuerban S, Saidula A, Lixiny I, Ping W, Ainiwaer R, Yasen W, et al. Blood purifying mixture for treating skin diseases. CN Patent 103830379. Available from: https://www.patentscope.wipo.int/search/ en/detail.jsf?docId $=\mathrm{CN} 105274255 \&$ redirectedID $=$ true. [Last cited on 2015 Oct 12]

53. Fengqin Y, Shengjie W. Physalisalkekengi heat-clearing throatwetting wine and production method thereof. CN Patent 103815400 2014. Available from: https://www.patentscope.wipo.int/search/en/ detail.jsf?docId $=$ CN97697098\&redirectedID $=$ true. $[$ Last cited on 2015 Oct 12]

54. Tongwei A, Qingzhong C, Jia G. Compound tincture for treatment of porcine virus diarrhea, preparation method and application thereof. $\mathrm{CN}$ Patent 103800804. 2014. Available from: https://www.patentscope. wipo.int/search/en/detail.jsf?docId $=$ CN97673714\&redirectedID $=$ true. [Last cited on 2015 Oct 12].

55. Fengqin Y, Shengjie W. Blueberry wine with functions of invigorating stomach and relieving diarrhea and production method thereof. CN Patent 103805422. 2014. Available from: https://www.patentscope. wipo.int/search/en/detail.jsf?docId $=$ CN97685595\&redirectedID $=$ true. [Last cited on 2015 Oct 12]

56. Qun Z. Traditional Chinese medicine effective part composition for treating chronic pharyngitis. CN Patent 103768138. 2014. Available from: https://www.patentscope.wipo.int/search/en/detail.jsf?docId= CN97456815\&redirectedID $=$ true. [Last cited on 2015 Oct 12]

57. Wenge Z, Chuansheng L, Yanli M, Ting S. Traditional Chinese medicinal decoction for treating bronchial asthma. CN Paten 103751674. 2014. Available from: https:/www.patentscope.wipo.int/ search/en/detail.jsf?docId $=\mathrm{CN} 97444765 \&$ redirectedID $=$ true. [Last cited on 2015 Oct 12]

58. Linxiang W, Yuwen W, Shaoqin C. Drug for treatment of rheumatoid arthritis and preparation method thereof. CN Patent 10375130 2014. Available from: https://www.patentscope.wipo.int/search/en/ detail.jsf?docId $=\mathrm{CN} 97436452 \&$ redirectedID $=$ true. [Last cited on 2015 Oct 12].

59. Banglin S. Traditional Chinese medicine preparation for treating tonsillitis and pharyngolaryngitis and preparation method thereof. CN Patent 103690695. 2014. Available from: https://www.patentscope. wipo.int/search/en/detail.jsf?docId $=$ CN97363310\&redirectedID $=$ true. [Last cited on 2015 Oct 12].

60. Zhaoshun H, Xiaoying C, Xue H, Bing H. Chinese herbal medicine feed for wide geese, wide ducks, African geese and wide chickens. CN Patent 103621837. 2014. Available from: https://www.patentscope. wipo.int/search/en/detail.jsf?docId= CN96911073\&redirectedID $=$ true [Last cited on 2015 Oct 12].

61. Zhen W. Traditional Chinese medicine(TCM) for treating allergic rhinitis CN Patent 103610788. 2014. Available from: https://www.patentscope. wipo.int/search/en/detail.jsf?docId= CN96890928\&redirectedID $=$ true. [Last cited on 2015 Oct 12]

62. Hong Z. Throat clearing and moistening healthcare tea. CN Paten 103493921. 2014. Available from: https://www.patentscope.wipo.int search/en/detail.jsf?docId= CN97998265\&redirectedID $=$ true. $[$ Last cited on 2015 Oct 12]

63. Thangavel G, Mukklil R, ChirakkalH, Kurian H, Schoeters E, Wouters H, et al. Plant parts and extracts having anticoccidial activity. WO Patent 2014004761. 2014. Available from: https:/www.patentscope.wipo.int/ search/en/detail.jsf?docId $=$ WO2014004761\&redirectedID $=$ true.$[$ Las cited on 2015 Oct 12]

64. Qing L. External powder for treating dental ulcer and preparation method thereof. CN Patent 103405578. 2014. Available from: https://www.patentscope.wipo.int/search/en/detail.jsf?docId= CN97906141\&redirectedID = true. [Last cited on 2015 Oct 12]

65. Ghosal S, Veeraragavan M, Kalidindi SR. Terminalia chebula compositions and method of extracting same. WO Patent 2013155175 2014. Available from: https://www.patentscope.wipo.int/search/en/ detail.jsf?docId $=$ WO2013155175\&redirectedID $=$ true. [Last cited on 2015 Oct 12].

66. Lee KW, Lee JY, Hong CO, Koo YC, Nam MH, Yang SY. Inhibitor and a breaker of an advance glycation end-products (AGEs) - induced crosslink, containing chebulic acid as an active ingredient. $\mathrm{Kr}$ Patent 1020130109874. 2014. Available from: https://www.patentscope.wipo. int/search/en/detail.jsf?docId $=\quad$ kr95738165\&recNum $=$ 2\&office= \&queryString $=\quad$ FP\%3A\%281020130109874\%29\&prevFilter \&sortOption $=$ Pub + Date + Desc $\&$ maxRec $=2$. $[$ Last cited on 2015 Oct 12]

67. Divya R, Kumar RR, Kunnambath R, Radhakrishna PM. Mouthwash composition for managing oral mucositis, process and methods thereof. US Patent 20130243702. 2014. Available from: 
https://www.patentscope.wipo.int/search/en/detail.jsf?docId= US91083848\&redirectedID $=$ true. [Last cited on 2015 Oct 12].

68. Liugui W, Jianying L. Quality control method of drug for treating cough CN Patent 103175938. 2014. Available from: https://www.patentscope. wipo.int/search/en/detail.jsf?docId $=$ CN91950202\&redirectedID $=$ true [Last cited on 2015 Oct 12]

69. Kim, Choi HB, Lim HT, Kim HJ, Lee JS, Bae JY, et al. Cosmetic composition containing Indian natural products for skin whitening. $\mathrm{Kr}$ Patent 1020130057542, 2014. Available from: https://www.patentscope. wipo.int/search/en/detail.jsf?docId $=$ kr95439272\&redirectedID $=$ true [Last cited on 2015 Oct 12]

70. Hongqi ZA. Chinese medicinal formulation for treating infiltrative pulmonary tuberculosis. CN Patent 102847026. 2013. Available from: https://www.patentscope.wipo.int/search/en/detail.jsf?docId= $\mathrm{CN} 85772836 \&$ redirectedID $=$ true. [Last cited on 2015 Oct 12].

71. Hongqi ZA. Chinese medicinal formulation for treating tuberculosis of intestine. $\mathrm{CN}$ Patent 102847027. 2013Available from: https://www.patentscope.wipo.int/search/en/detail.jsf?docId=

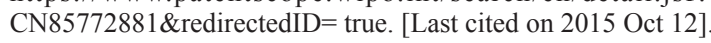

72. Yang X, Qiongguang Z, Fuliang X. Traditional Chinese medicine for treating fungal skin infection. CN Patent 102824518. 2013. Available from: https://www.patentscope.wipo.int/search/en/detail.jsf?docId= CN85444998\&redirectedID $=$ true. [Last cited on 2015 Oct 12]

73. Pengcuo J. Traditional Tibetan medicine for treating alopecia. CN Patent 102784216. 2013. Available from: https://www.patentscope.

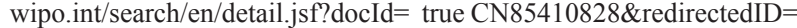
. [Last cited on 2015 Oct 12].

74. Junjie $X$. Traditional Chinese medicine preparation for treating viral enteritis and diarrhea. CN Patent 102670936. 2013. Available from: https://www.patentscope.wipo.int/search/en/detail.jsf?docId= $\mathrm{CN} 85312413 \&$ redirectedID $=$ true. [Last cited on 2015 Oct 12]

75. Unilever Herb extract for cognitive health benefit. EP Paten 2486932. 2012. Available from: https://www.patentscope.wipo. int $/$ search/en/detail.jsf?docId $=\quad$ EP73124109\&recNum $=$ 2\&office= \&queryString $=\mathrm{FP} \% 3 \mathrm{~A} \% 282486932 \% 29 \&$ prevFilter= \&sortOption= Pub + Date + Desc $\& \max R e c=6$. [Last cited on 2015 Oct 12]

76. Changtao W, Xiaotao S, Xingding C, Shuang W. Antioxidant active compound of Terminalia chebula and preparation method thereof. CN Patent 102526136. 2012. Available from: https://www.patentscope. wipo.int $/$ search/en/detail.jsf?docId $=\mathrm{CN} 85165872$ \& redirectedID $=$ true [Last cited on 2015 Oct 12].

77. Eileen KP, Awerkwei QR. Hair treatment composition. EP Paten 2467191. 2012. Available from: https://www.patentscope.wipo. int $/$ search/en/detail.jsf?docId $=$ EP57543417\& recNum $=3 \&$ office $=$ \&queryString $=\mathrm{FP} \% 3 \mathrm{~A} \% 282467191 \% 29 \&$ prevFilter= \&sortOption= Pub+Date+Desc \&maxRec $=6$. [Last cited on 2015 Oct 12]

78. Eileen KP. Hair treatment composition. US Patent 20120138079. 2012 Available from: https://www.patentscope.wipo.int/search/en/detail jsf?docId $=$ US73585302\&redirectedID $=$ true. [Last cited on 2015 Oct 12]
79. Divya R, Kumar RK, Ramadas R, Pillai K, Radhakrishna M A mouthwash composition for managing oral mucositis, process and methods thereof. WO Patent 2012059874. 2012. Available from: https://www.patentscope.wipo.int/search/en/detail.jsf?docId= WO2012059874\&redirectedID $=$ true. [Last cited on 2015 Oct 12]

80. Namita D. Plant extracts, compositions containing same, and uses thereof. US Patent 20120027697. 2012. Available from: https://www.patentscope.wipo.int/search/en/detail.jsf?docId= US73474925\&redirectedID $=$ true. [Last cited on 2015 Oct 12]

81. Hui L. Chinese composition for treating rhinitis. CN Patent 102284035 2011. Available from: https://www.psatentscope.wipo.int/search/en/

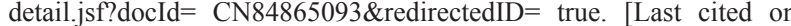
2015 Oct 12].

82. Han SL. Pharmaceutical composition containing Terminalia chebula Retzius extarct for or treating dermatitis. Kr Patent 1020110108825. 2011. Available from: https://www.patentscope.wipo.int/search/en/ detail.jsf?docId $=$ kr45543869\&recNum $=2 \&$ office $=$ \&queryString= FP\%3A\%281020110108825\%29\&prevFilter= \&sortOption= Pub+Date+Desc\&maxRec $=2$. [Last cited on 2015 Oct 12]

83. Morawala PV. Screening method (metabolite grid) for therapeutic extracts and molecules for diabetes. US Patent 20110159118 2011. Available from: https://www.patentscope.wipo.int/search/en/ detail.jsf?docId $=$ US73285153\&redirectedID $=$ true. $[$ Last cited on 2015 Oct 12]

84. Chai NY, Jung YG, Kim KH, Choi KS, Sun K. NF-kappa B inhibitor containing Terminalia chebula fruit extarct. Kr Patent 1020110073241. 2011. Available from: https://www.patentscope.wipo.int/search/en/ detail.jsf?docId $=$ kr45510446\&recNum $=2 \&$ office $=$ \&queryString $=$ FP\%3A\%281020110073241\%29\&prevFilter= \&sortOption= Pub + Date + Desc\&maxRec $=2$. [Last cited on 2015 Oct 12]

85. Zhiying $\mathrm{C}$, Linsheng L, Xiaohong Y, Chunling C, Dexiu W, Dexiu Q. Compound Terminalia chebula Retz throat lozenge and preparation method thereof. CN Patent 102100326. 2011. Available from: https://www.patentscope.wipo.int/search/en/detail.jsf?docId=

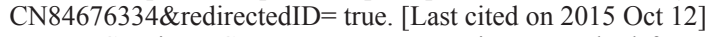

86. Yoon HG, Kim HG, Lee MI, Jun YH, Jin W. Method for preparing Terminalia chebula extract for preventing or treating prostate cancer. $\mathrm{Kr}$ Patent 1020110048133. 2011. Available from: https://www.patentscope. wipo.int/search/en/detail.jsf?docId $=$ kr30062298\&recNum $=2 \&$ office= \&queryString $=\quad$ FP\%3A\%281020110048133\%29\&prevFilter= $\&$ sortOption $=\mathrm{Pub}+\mathrm{Date}+\mathrm{Desc} \& \operatorname{maxRec}=2$. [Last cited ON 2015 Oct 12].

87. Penelope K, Quartey E, Awerkwei R. Hair treatment composition. WO Patent 2011020833. 2010. Available from: https://www.patentscope. wipo.int $/$ search/en/detail.jsf?docId $=$ WO2011020833\&redirectedID $=$ true. [Last cited on 2015 Oct 12].

88. Yi ZC, Wang Z, Li HX, Liu MJ, Wu RC, Wang XH. Effects of chebulinic acid on differentiation of human leukemia K562 cells. Acta Pharmaco Sin $2004 ; 25(2): 231-8$ 